\title{
Downregulation of Reactive Oxygen Species in Apoptosis
}

\author{
Chul-Ho Jeong ${ }^{1}$, Sang Hoon Joo ${ }^{2}$ \\ ${ }^{1}$ College of Pharmacy, Keimyung University, Daegu, ${ }^{2}$ Department of Pharmacy, Catholic University of Daegu, Gyeongsan, Korea
}

\begin{abstract}
Generation of reactive oxygen species (ROS) by diverse anti-cancer drugs or phytochemicals has been closely related with the induction of apoptosis in cancers. Also, the downregulation of ROS by these chemicals has been found to block initiation of carcinogenesis. Therefore, modulation of ROS by phytochemicals emerges as a crucial mechanism to regulate apoptosis in cancer prevention or therapy. This review summarizes the current understanding of the selected chemical compounds and related cellular components that modulate ROS during apoptotic process. Metformin, quercetin, curcumin, vitamin C, and other compounds have been shown to downregulate ROS in the cellular apoptotic process, and some of them even induce apoptosis in cancer cells. The cellular components mediating the downregulation of ROS include nuclear factor erythroid 2-related factor 2 antioxidant signaling pathway, thioredoxin, catalase, glutathione, heme oxygenase-1, and uncoupling proteins. The present review provides information on the relationship between these compounds and the cellular components in modulating ROS in apoptotic cancer cells.
\end{abstract}

(J Cancer Prev 2016;21:13-20)

Key Words: Reactive oxygen species, Apoptosis, Neoplasms

\section{INTRODUCTION}

The increase of reactive oxygen species (ROS) is often observed in the progress of apoptosis, ${ }^{1,2}$ and the generation/ upregulation of ROS can be an indication of apoptosis. Indeed, many anticancer drugs and natural compounds (curcumin, ${ }^{3}$ garlic, ${ }^{4}$ quercetin, ${ }^{1}$ cisplatin, etc.) have been known to increase the level of ROS as they induce the apoptosis in cancer cells. While the increase of ROS usually correlates with the apoptotic progress, the downregulation of ROS in apoptotic cancer cells is often observed. While it may seem perplexing at first glance, it is plausible considering the beneficial and essential roles of ROS in physiological conditions.

In this review, we have summarized the current understanding of the selected chemical compounds (Fig. 1) and the related cellular components which modulate ROS during the apoptotic process (Fig. 1). The studies on the apoptotic or anti-apoptotic effects of metformin, quercetin, curcumin, vitamin C, and other compounds in diverse cancer cells are presented (Table 1), followed by the cellular components, including nuclear factor-erythroid2-related factor 2 (Nrf2) antioxidant signaling pathway, thioredoxin (TRX), catalase, glutathione (GSH), heme oxygenase-1 (HO-1), and uncoupling proteins (UCPs). We focus here on the cell-specific downregulation of ROS by selected chemicals as a modulator of apoptosis.

\section{NATURAL/SYNTHETIC ANTIOXIDANTS THAT DOWNREGULATE REACTIVE OXYGEN SPECIES}

\section{Metformin}

Metformin is an oral antidiabetic medication to treat type 2 diabetes. It enhances insulin sensitivity by increasing glucose uptake and utilization in peripheral tissues. These effects are

Received February 17, 2016, Revised February 28, 2016, Accepted February 29, 2016

Correspondence to: Sang Hoon Joo

Department of Pharmacy, Catholic University of Daegu, 13-13 Hayang-ro, Hayang-eup, Gyeongsan 38430, Korea

Tel: +82-53-850-3614, Fax: +82-53-359-6729, E-mail: sjoo@cu.ac.kr, ORCID: Sang Hoon Joo, http://orcid.org/0000-0001-8660-884X

Copyright (C) 2016 Korean Society of Cancer Prevention

(c) This is an Open Access article distributed under the terms of the Creative Commons Attribution Non-Commercial License (http://creativecommons.org/licenses/by-nc/4.0) which permits unrestricted non-commercial use, distribution, and reproduction in any medium, provided the original work is properly cited. 
A<smiles>CN(C)C(=N)NC(=N)N</smiles>

B<smiles>O=c1c(O)c(-c2ccc(O)c(O)c2)oc2cc(O)cc(O)c12</smiles>

C<smiles>O=C1c2c(O)cc(O)cc2O[C@@H](c2cc(O)c(O)c(O)c2)[C@@H]1O</smiles>

E<smiles>CC1OC(OCC2OC(Oc3c(-c4ccc(O)c(O)c4)oc4cc(O)cc(O)c4c3=O)C(O)C(O)C2O)C(O)C(O)C1O</smiles>

Figure 1. Chemical structures of natural/synthetic compounds. Metformin (A). Quercetin (B). Dihydromyricetin (C). Curcumin (D). Rutin (E). Spirafolide (F). Vitamin C (G).

Table 1. Cell-specific modulation of ROS generation by selected compounds

\begin{tabular}{|c|c|c|c|c|}
\hline Compound & Cell type & Effect on ROS & Cellular effect & Reference \\
\hline Metformin & Renal tubular cells, fatty liver cells & Decrease & Anti-apoptotic & 13,15 \\
\hline Metformin & Pancreatic cancer cells & Decrease & Apoptotic & 16 \\
\hline Quercetin & Hepatoma, leukemia & Increase & Apoptotic & 24,25 \\
\hline Quercetin & HUVEC cells & Decrease & Anti-apoptotic & 26 \\
\hline Curcumin & Renal, skin, fibroblast, lung adenocarcinoma & Decrease & Anti-apoptotic & $3,30,31,32$ \\
\hline Curcumin & Neuroblastoma & Increase & Apoptotic & 33 \\
\hline Vitamin C & WISH & Decrease & Anti-apoptotic & 36 \\
\hline Vitamin C & B16 murine cells & Increase & Apoptotic & 38 \\
\hline Spirafolide & Neuroblastoma & Decrease & Anti-apoptotic & 39 \\
\hline Retinoic acid & Neuron, cardiomyocyte & Decrease & Anti-apoptotic & 41,42 \\
\hline Retinoic acid & HL60 cells & Increase & Apoptotic & 44 \\
\hline Dihydromyricetin & Hepatocarcinoma & Decrease & Apoptotic & 45,46 \\
\hline Dihydromyricetin & Lymphocytes, PC12 & Decrease & Anti-apoptotic & 47,48 \\
\hline
\end{tabular}

ROS, reactive oxygen species. 
mainly mediated by the activation of AMP-activated protein kinase (AMPK). Quite recently, metformin was suggested to be related with the reduced risk of cancer in diabetic patients. ${ }^{6,7}$ While the mechanism by which metformin protects against cancer is veiled yet, metformin has been reported to decrease ROS in several cases. Metformin, at the pharmacological level of $\sim 10^{-5}$ $\mathrm{mol} / \mathrm{L}$, lowered the level of ROS in bovine aortic endothelial cells. ${ }^{8}$ The production of ROS in endothelial cells, upon glucose-induction, is mainly mediated by several pathways of hyperglycemic responses, including the activation of protein kinase $\mathrm{C}$ (PKC). ${ }^{9}$ Metformin inhibited the activity of PKC, although it does not have direct inhibitory activity against PKC in vitro. It appears that metformin inhibits the upstream of the activation of PKC, such as membrane translocation of PKC. ${ }^{10}$ The AMPK pathway, activated by metformin, increased the expression of the TRX through forkhead transcription factor 3, and the TRX functions as antioxidant to reduce the ROS. ${ }^{11}$ The decrease of ROS could reduce the DNA damage, and possibly the risk of cancer. ${ }^{12}$ Metformin inhibited the advanced glycation end product-induced apoptosis in renal tubular cells through ROS reduction mediated by the activation of AMPK pathway. ${ }^{13}$ The role of the AMPK in the reduction of ROS is not essential, as metformin decreases the ROS even in the AMPK-deficient cells. ${ }^{14}$ Moreover, the protective effect of metformin was observed in the fatty liver cell under oxidative stress, probably due to the increased antioxidant enzyme activity, lower ROS production, and reduction of inflammation. ${ }^{15}$ While the role of metformin was mostly related with cell protective effects, it was recently reported that metformin decreased the growth of pancreatic cancer cells by reducing ROS production. ${ }^{16}$

\section{Quercetin}

Quercetin is a widespread flavonoid compound from numerous vegetables and fruits. At least $50 \mathrm{mg}$ of quercetin is estimated to be present in a daily diet. ${ }^{17}$ Several clinically relevant functions of quercetin are antihypertensive, anti-inflammatory, hypocholesterolaemic, and antitumor activity. ${ }^{18}$ Early studies reported quercetin as a mutagenic compound in the Ames test. ${ }^{19,20}$ However, later studies indicated anticancer activity of quercetin. $^{21,22}$ Interestingly, quercetin has both pro-oxidative and anti-oxidative properties depending on the redox state of the biological environment. ${ }^{23}$ In relation with the apoptosis, quercetin induced the generation of ROS, resulting in apoptosis in hepatoma cells ${ }^{24}$ and leukemia cells. ${ }^{25}$ Therefore, the pro-apoptotic role of quercetin appears to be related with the upregulation of ROS, not the downregulation. In contrast, the downregulation of ROS by rutin, a quercetin glycoside, was observed in the hydrogen peroxide-induced apoptosis of human umbilical vein endothelial cells. ${ }^{26}$

\section{Curcumin}

Curcumin is a yellow pigment obtained from the root of the Indian turmeric (Curcuma longa). It has been used as a foodstuff, cosmetic, and herbal medicine for a long time. The reported biological activities of curcumin include antioxidant, antiinflammatory, ${ }^{27}$ anticancer, ${ }^{28}$ and chemoprevention, ${ }^{29}$ etc. Curcumin has been reported to induce apoptosis in numerous cells, including human renal Caki cells, ${ }^{3}$ skin squamous cell carcinoma COLO-16, ${ }^{30}$ mouse fibroblast L929 cells, ${ }^{31}$ and human lung adenocarcinoma 4549 cells. ${ }^{32}$ In these cases, the induction of ROS mediated the apoptosis. These pro-apoptotic roles of curcumin seem to be involved in the upregulation of ROS, and the downregulation of ROS inhibited the apoptosis of SH-SY5Y cells. ${ }^{33}$

\section{Vitamin C}

Vitamin $C$ is an essential nutrient in human, and it functions as an electron donor for many enzymatic reactions. It is widely accepted that vitamin $\mathrm{C}$ is an antioxidant, and the reduction of ROS by vitamin $C$ treatment has been reported in the TRAILinduced apoptosis ${ }^{34}$ and the oxidized low density lipoprotein (LDL)-induced apoptosis. ${ }^{35}$ The reduction of ROS resulted in the protection of the cells from apoptotic damage. On the other hand, vitamin $\mathrm{C}$ was not effective in the inhibition of the $\mathrm{H}_{2} \mathrm{O}_{2}$-induced apoptosis. $^{36}$ Interestingly, the $\mathrm{H}_{2} \mathrm{O}_{2}$-induced apoptosis was preferably exacerbated by vitamin $\mathrm{C}^{37}$ Also, vitamin $\mathrm{C}$ induced the apoptosis of B16 murine melanoma cells by increasing ROS. ${ }^{38}$ Therefore, the role of vitamin $\mathrm{C}$ as an antioxidant in the apoptosis is controversial.

\section{Other compounds}

Spirafolide is a compound purified from the leaves of Laurus nobilis L. It has been reported to decrease the ROS level, thereby inhibited dopamine-induced apoptosis in human neuroblastoma SH-SY5Y cells. ${ }^{39}$ Fructose, when used as sole carbon source instead of glucose, reduced ROS and stabilized of cellular GSH pool as efficient as $\mathrm{N}$-acetyl-cystein in the oxidative stress-induced apoptosis in liver parenchymal cells. ${ }^{40}$

Retinoic acid, a metabolite of vitamin A metabolism, has been shown to suppress ROS production and inhibit the staurosporineinduced apoptosis. ${ }^{41}$ Previous study indicated that treatment with retinoic acid prevented angiotensin II-induced apoptosis in cardiomyocyte by decreasing ROS generation. ${ }^{42}$ However, the 
upregulation of ROS by retinoic acid was also reported in promyelocytic leukemia, ${ }^{43}$ which resulted in apoptosis of granulocyte-differentiated HL60 cells. ${ }^{44}$ Consistently, it was accepted that the downregulation of ROS by retinoic acids was related with the prevention of apoptosis.

Dihydromyricetin, a flavonoid compound, was recently shown to induce the apoptosis of human hepatocarcinoma cells by decreasing ROS generation. ${ }^{45.46}$ In addition, it is noteworthy that the downregulation of the ROS by dihydromyricetin could block $\mathrm{H}_{2} \mathrm{O}_{2}$-induced apoptosis of MT-4 lymphocytes ${ }^{47}$ and $\mathrm{PC} 12$ cells. $^{48}$ These results suggest that the downregulation of ROS can differently modulate apoptosis depending on the cell types.

\section{ENDOGENOUS CELLULAR COMPONENTS INVOLVED WITH THE DOWNREGULATION OF REACTIVE OXYGEN SPECIES}

\section{Nuclear factor erythroid 2-related factor 2 antioxi- dant signaling pathway}

Nrf2 is a basic leucine zipper transcriptional activator. ${ }^{49}$ In non-stressed cells, Nrf2 is constantly degraded through ubiquitin-proteasome pathway mainly regulated by Keap1 protein. ${ }^{50}$ In the presence of ROS, activated Nrf2 can act as a master regulator of several genes for antioxidant enzymes and detoxifying enzymes by binding activated antioxidant response elements. ${ }^{51}$ Those enzymes are NAD(P)H:quinone oxidoreductase (NQO1), ${ }^{52}$ glutathione S-transferase, ${ }^{53}$ and HO-1..$^{54}$ The protective role of Nrf2 signaling pathway in the apoptotic process was evident. Nrf2 mediated the expression of HO-1 and NQO1, thereby protected cells from the $\mathrm{Cr}(\mathrm{VI})$ induced-apoptosis. ${ }^{55}$ Upregulation of HO-1 by Nrf2 rescued PC12 cells from $\mathrm{H}_{2} \mathrm{O}_{2}$-induced apoptosis. ${ }^{56}$ Moreover, the presence of $\mathrm{Nrf} 2$ increased the level of TRX, thereby protected human dopaminergic neuroblastoma SH-SY5Y cells from the paraquat-induced cell death. ${ }^{57}$ In addition to antioxidant proteins, Nrf2 also regulated the expression of anti-apoptotic protein Bcl-2. ${ }^{58}$ While Nrf2 signaling pathway showed the anti-apoptotic effect in most cases, constitutively active Nrf2 enhanced the apoptosis of damaged liver cells. ${ }^{59}$ It might be possible to modulate the activity of Nrf2 to either protect or damage the cells. $^{60}$

\section{Thioredoxin}

TRX is an oxidoreductase enzyme containing dithiol-disulfide active site. ${ }^{61}$ There are TRX isoforms in most organisms, and there exist separate TRX system for cytoplasm and mitochondria. TRX functions as a protein disulfide reductase and an electron donor for other enzymes such as ribonucleotide reductase and peroxidase. ${ }^{62}$ Conditional knockout of a mitochondrial enzyme TRX-2 resulted in the induction of apoptosis in chicken B-cell lines, DT40, ${ }^{63}$ and overexpression of TRX-2 inhibited the TNF- $\alpha$-induced apoptosis of HeLa cells ${ }^{64}{ }^{6}$ indicating the anti-apoptotic role of TRX. Moreover, TRX inhibited apoptosis signal-regulating kinase 1 (ASK1) by promoting the ubiquitination of ASK1, demonstrating the role of TRX beyond ROS removal. ${ }^{65}$ In most cases, TRX has been shown to possess a protective and anti-apoptotic function. However, the pro-apoptotic role of TRX was also reported in the anthracycline-induced apoptosis of MCF-7 breast cancer cells. The expression of the redox-inactive mutant TRX resulted in decreased superoxide generation and apoptosis. ${ }^{66}$

\section{Catalase}

Catalase is a peroxisomal enzyme that converts hydrogen peroxide, a ROS, into water and oxygen. Inhibition of catalase can result in the increase in ROS and oxidative damage. Indeed, TGF- $\beta 1$-induced suppression of the expression/activity of catalase caused the apoptosis of hamster pancreatic beta-cell line. ${ }^{67}$ On the other hand, the overexpression of catalase could attenuate the apoptosis induced by oxidized LDL stimulation ${ }^{68}$ and UV-B radiation. ${ }^{69}$ Catalase showed a protective and anti-apoptotic role in most cases by eliminating ROS. Nevertheless, it was also reported that the overexpression of human catalase inhibited proliferation and promoted the apoptosis of vascular smooth muscle cells. ${ }^{70}$

\section{Glutathione}

GSH is a tripeptide compound containing cysteine present in animal, plant, and fungi. It serves as an antioxidant with the free thiol group of cysteine residue. The oxidized form of GSH (GSSG) contains two GSH with disulfide linkage, and the ratio of GSH vs. GSSG can be a good measure of redox state of the cell. ${ }^{71}$ The protective and anti-apoptotic role of GSH was shown in MDBK bovine renal epithelial cells: the selenium-dependent GSH peroxidase (GPx) protected the cells against the $\mathrm{H}_{2} \mathrm{O}_{2}$-induced apoptosis, ${ }^{72}$ whereas the suppression of GPx enhanced the $\mathrm{H}_{2} \mathrm{O}_{2}$-induced apoptosis. ${ }^{67}$ Therefore, GSH depletion is closely correlated with the apoptotic induction in most cases, and the protective and anti-apoptotic role of GSH might be due to its antioxidant function. 


\section{Heme oxygenase-1}

HO-1 is a stress-responsive enzyme catalyzing the degradation of heme into carbon monoxide (CO), biliverdin, and iron $\left(\mathrm{Fe}^{2+}\right){ }^{73}$ The HO-1-inducing stress stimuli include X-ray-induced oxidative stress, ${ }^{74}$ hypoxia, ${ }^{75}$ and ultraviolet. ${ }^{76}$ All three products of HO-1 reaction serve as antioxidants and have other protective roles against apoptosis. Pharmacological upregulation of HO-1 prevented the glutamate-induced apoptosis of cerebral vascular endothelial cells. ${ }^{77}$ Upregulation of HO-1 protected human keratinocyte (HaCaT) cells against UV-A-induced oxidative stress. ${ }^{78}$ However, it does not always imply that the induction of HO-1 plays a protective role in cells against apoptosis, considering that induction of HO-1 increased in the Nickel (II)-induced apoptosis of human Jurkat cells. ${ }^{79}$ This might be resulted from the response of cells to the increased level of ROS. It appears that the expression of HO-1 has to do with the reduction of ROS as seen in the dihydromyricetin-induced apoptosis of human hepatoma HepG2 cells. ${ }^{45}$

\section{Uncoupling proteins}

UCPs are mitochondrial inner membrane proteins, and they dissipate proton gradient. The physiological roles contain heat generation as in hibernation, cold exposure, and normal body temperature. In addition, UCP2 has been shown to modulate the mitochondrial generation of $\mathrm{H}_{2} \mathrm{O}_{2}{ }^{80}$ Splenocytes, resistant to oxidative stress-induced apoptosis, have been reported to show high level of UCP2 expression. ${ }^{81}$ Overexpression of UCP2 inhibited ROS generation and blocked the apoptosis in human aortic endothelial cells induced by lysophophatidylcholine. ${ }^{82}$ The inhibition of UCP2, on the contrary, exacerbated the apoptosis in kidney cells. ${ }^{83}$ Several other reports also supported the anti-apoptotic function of UCP2 through the downregulation of ROS.

\section{CONCLUSION}

We have summarized the controversial role of selected natural/synthetic compounds in modulating cell apoptosis by different regulation of ROS generation. Because the cellular components mediating the downregulation of ROS have not been tied up with corresponding compounds yet, further study in this field is required to establish clearer relationship between these compounds and the cellular components in cancer cells. These natural/synthetic compounds can be useful in modulating the apoptotic process, and in providing new strategies in cancer prevention and therapy.

\section{ACKNOWLEDGMENTS}

This study was supported by College of Pharmacy-specialized Research Fund (from Institute for New Drug Development) of Keimyung University and Basic Science Research Program through the National Research Foundation of Korea (NRF) funded by the Ministry of Education (2014R1A1A2054979).

\section{CONFLICTS OF INTEREST}

No potential conflicts of interest were disclosed.

\section{REFERENCES}

1. Matés JM, Sánchez-Jiménez FM. Role of reactive oxygen species in apoptosis: implications for cancer therapy. Int J Biochem Cell Biol 2000;32:157-70.

2. Simon HU, Haj-Yehia A, Levi-Schaffer F. Role of reactive oxygen species (ROS) in apoptosis induction. Apoptosis 2000;5:415-8.

3. Woo JH, Kim YH, Choi YJ, Kim DG, Lee KS, Bae JH, et al. Molecular mechanisms of curcumin-induced cytotoxicity: induction of apoptosis through generation of reactive oxygen species, down-regulation of Bcl-XL and IAP, the release of cytochrome $c$ and inhibition of Akt. Carcinogenesis 2003;24:1199-208.

4. Dirsch VM, Gerbes AL, Vollmar AM. Ajoene, a compound of garlic, induces apoptosis in human promyeloleukemic cells, accompanied by generation of reactive oxygen species and activation of nuclear factor kappaB. Mol Pharmacol 1998:53:402-7.

5. Berndtsson M, Hägg M, Panaretakis T, Havelka AM, Shoshan MC, Linder S. Acute apoptosis by cisplatin requires induction of reactive oxygen species but is not associated with damage to nuclear DNA. Int J Cancer 2007;120:175-80.

6. Evans JM, Donnelly LA, Emslie-Smith AM, Alessi DR, Morris AD. Metformin and reduced risk of cancer in diabetic patients. BMJ 2005:330:1304-5.

7. Decensi A, Puntoni M, Goodwin P, Cazzaniga M, Gennari A, Bonanni B, et al. Metformin and cancer risk in diabetic patients: a systematic review and meta-analysis. Cancer Prev Res (Phila) 2010;3:1451-61

8. Ouslimani N, Peynet J, Bonnefont-Rousselot D, Thérond P, Legrand A, Beaudeux JL. Metformin decreases intracellular production of reactive oxygen species in aortic endothelial cells. Metabolism 2005:54:829-34.

9. Nishikawa T, Edelstein D, Du XL, Yamagishi S, Matsumura T, Kaneda $Y$, et al. Normalizing mitochondrial superoxide production blocks three pathways of hyperglycaemic damage. Nature 2000;404:787-90.

10. Mahrouf M, Ouslimani N, Peynet J, Djelidi R, Couturier M, Therond $\mathrm{P}$, et al. Metformin reduces angiotensin-mediated intracellular production of reactive oxygen species in endothelial cells through the inhibition of protein kinase C. Biochem Pharmacol 
2006; 72:176-83

11. Hou X, Song J, Li XN, Zhang L, Wang X, Chen L, et al. Metformin reduces intracellular reactive oxygen species levels by upregulating expression of the antioxidant thioredoxin via the AMPKFOXO3 pathway. Biochem Biophys Res Commun 2010;396:199-205.

12. Algire $C$, Moiseeva $O$, Deschênes-Simard X, Amrein L, Petruccelli $\mathrm{L}$, Birman E, et al. Metformin reduces endogenous reactive oxygen species and associated DNA damage. Cancer Prev Res (Phila) 2012;5:536-43.

13. Ishibashi Y, Matsui T, Takeuchi M, Yamagishi S. Metformin inhibits advanced glycation end products (AGEs)-induced renal tubular cell injury by suppressing reactive oxygen species generation via reducing receptor for AGEs (RAGE) expression. Horm Metab Res 2012;44:891-5.

14. Kelly B, Tannahill GM, Murphy MP, O'Neill LA. Metformin inhibits the production of reactive oxygen species from $\mathrm{NADH}$ : ubiquinone oxidoreductase to limit induction of interleukin-1 $\beta$ (IL-1 $\beta$ ) and boosts interleukin-10 (IL-10) in lipopolysaccharide (LPS)-activated macrophages. J Biol Chem 2015;290:20348-59.

15. Cahova M, Palenickova E, Dankova H, Sticova E, Burian M, Drahota $Z$, et al. Metformin prevents ischemia reperfusion-induced oxidative stress in the fatty liver by attenuation of reactive oxygen species formation. Am J Physiol Gastrointest Liver Physiol 2015;309:G100-11.

16. Cheng G, Lanza-Jacoby S. Metformin decreases growth of pancreatic cancer cells by decreasing reactive oxygen species: role of NOX4. Biochem Biophys Res Commun 2015;465:41-6.

17. Brown JP. A review of the genetic effects of naturally occurring flavonoids, anthraquinones and related compounds. Mutat Res 1980;75:243-77.

18. Formica JV, Regelson W. Review of the biology of Quercetin and related bioflavonoids. Food Chem Toxicol 1995;33:1061-80.

19. Bjeldanes LF, Chang GW. Mutagenic activity of quercetin and related compounds. Science 1977;197:577-8.

20. Rueff J, Laires A, Gaspar J, Borba H, Rodrigues A. Oxygen species and the genotoxicity of quercetin. Mutat Res 1992;265:75-81.

21. Chang RL, Huang MT, Wood AW, Wong CQ, Newmark HL, Yagi H, et al. Effect of ellagic acid and hydroxylated flavonoids on the tumorigenicity of benzo[a]pyrene and (+/-)-7 beta, 8 alpha-dihydroxy-9 alpha, 10 alpha-epoxy-7,8,9,10-tetrahydrobenzo[a]pyrene on mouse skin and in the newborn mouse. Carcinogenesis 1985;6:1127-33.

22. Nixon JE, Hendricks JD, Pawlowski NE, Pereira CB, Sinnhuber RO, Bailey GS. Inhibition of aflatoxin B1 carcinogenesis in rainbow trout by flavone and indole compounds. Carcinogenesis 1984;5: 615-9.

23. Sahu SC, Washington MC. Effect of ascorbic acid and curcumin on quercetin-induced nuclear DNA damage, lipid peroxidation and protein degradation. Cancer Lett 1992;63:237-41.

24. Chang YF, Chi CW, Wang JJ. Reactive oxygen species production is involved in quercetin-induced apoptosis in human hepatoma cells. Nutr Cancer 2006;55:201-9.

25. Lee WJ, Hsiao M, Chang JL, Yang SF, Tseng TH, Cheng CW, et al. Quercetin induces mitochondrial-derived apoptosis via reactive oxygen species-mediated ERK activation in HL-60 leukemia cells and xenograft. Arch Toxicol 2015;89:1103-17.

26. Gong G, Qin Y, Huang W, Zhou S, Yang X, Li D. Rutin inhibits hydrogen peroxide-induced apoptosis through regulating reactive oxygen species mediated mitochondrial dysfunction pathway in human umbilical vein endothelial cells. Eur J Pharmacol 2010; 628:27-35

27. Menon VP, Sudheer AR. Antioxidant and anti-inflammatory properties of curcumin. Adv Exp Med Biol 2007;595:105-25.

28. Agrawal DK, Mishra PK. Curcumin and its analogues: potential anticancer agents. Med Res Rev 2010;30:818-60.

29. Jiao Y, Wilkinson J 4th, Di X, Wang W, Hatcher H, Kock ND, et al. Curcumin, a cancer chemopreventive and chemotherapeutic agent, is a biologically active iron chelator. Blood 2009;113:462-9.

30. Hail N Jr. Mitochondrial reactive oxygen species affect sensitivity to curcumin-induced apoptosis. Free Radic Biol Med 2008;44: 1382-93.

31. Thayyullathil F, Chathoth S, Hago A, Patel M, Galadari S. Rapid reactive oxygen species (ROS) generation induced by curcumin leads to caspase-dependent and -independent apoptosis in L929 cells. Free Radic Biol Med 2008;45:1403-12.

32. Chen $\mathrm{Q}$, Wang Y, Xu K, Lu G, Ying Z, Wu L, et al. Curcumin induces apoptosis in human lung adenocarcinoma A549 cells through a reactive oxygen species-dependent mitochondrial signaling pathway. Oncol Rep 2010;23:397-403.

33. Uğuz AC, Öz A, Nazıroğlu M. Curcumin inhibits apoptosis by regulating intracellular calcium release, reactive oxygen species and mitochondrial depolarization levels in SH-SY5Y neuronal cells. [published online ahead of print November 25, 2015]. J Recept Signal Transduct Res. doi: 10.3109/10799893.2015.1108337.

34. Perez-Cruz I, Cárcamo JM, Golde DW. Caspase-8 dependent TRAIL-induced apoptosis in cancer cell lines is inhibited by vitamin C and catalase. Apoptosis 2007;12:225-34.

35. Siow RC, Richards JP, Pedley KC, Leake DS, Mann GE. Vitamin C protects human vascular smooth muscle cells against apoptosis induced by moderately oxidized LDL containing high levels of lipid hydroperoxides. Arterioscler Thromb Vasc Biol 1999;19: 2387-94.

36. Kumar D, Lundgren DW, Moore RM, Silver RJ, Moore JJ. Hydrogen peroxide induced apoptosis in amnion-derived WISH cells is not inhibited by vitamin C. Placenta 2004;25:266-72.

37. Kumar D, Moore RM, Elkhwad M, Silver RJ, Moore JJ. Vitamin C exacerbates hydrogen peroxide induced apoptosis and concomitant PGE2 release in amnion epithelial and mesenchymal cells, and in intact amnion. Placenta 2004:25:573-9.

38. Kang JS, Cho D, Kim YI, Hahm E, Yang Y, Kim D, et al. L-ascorbic acid (vitamin $\mathrm{C}$ ) induces the apoptosis of B16 murine melanoma cells via a caspase-8-independent pathway. Cancer Immunol Immunother 2003:52:693-8.

39. Ham A, Kim B, Koo U, Nam KW, Lee SJ, Kim KH, et al. Spirafolide from bay leaf (Laurus nobilis) prevents dopamine-induced apoptosis by decreasing reactive oxygen species production in human neuroblastoma SH-SY5Y cells. Arch Pharm Res 2010;33:1953-8.

40. Frenzel J, Richter J, Eschrich K. Fructose inhibits apoptosis induced by reoxygenation in rat hepatocytes by decreasing reactive oxygen species via stabilization of the glutathione pool. Biochim Biophys Acta 2002;1542:82-94.

41. Ahlemeyer B, Krieglstein J. Retinoic acid reduces staurosporineinduced apoptotic damage in chick embryonic neurons by suppressing reactive oxygen species production. Neurosci Lett 1998; 246:93-6.

42. Choudhary R, Baker KM, Pan J. All-trans retinoic acid prevents angiotensin II- and mechanical stretch-induced reactive oxygen species generation and cardiomyocyte apoptosis. J Cell Physiol 
2008:215:172-81

43. Ohno E, Ohtsuka E, Saburi Y, Ono K, Kikuchi H, Nasu M. Reactive oxygen species production of neutrophils in patients with acute promyelocytic leukemia during treatment with all-trans retinoic acid. Am J Hematol 1999;62:120-1.

44. Wang CY, Yang TT, Chen CL, Lin WC, Lin CF. Reactive oxygen species-regulated glycogen synthase kinase- $3 \beta$ activation contributes to all-trans retinoic acid-induced apoptosis in granulocyte-differentiated HL60 cells. Biochem Pharmacol 2014;88:86-94.

45. Liu B, Tan X, Liang J, Wu S, Liu J, Zhang Q, et al. A reduction in reactive oxygen species contributes to dihydromyricetin-induced apoptosis in human hepatocellular carcinoma cells. Sci Rep 2014; 4:7041.

46. Liu B, Zhou W, Chen X, Xu F, Chen Y, Liu J, et al. Dihydromyricetin induces mouse hepatoma Hepal- 6 cell apoptosis via the transforming growth factor- $\beta$ pathway. Mol Med Rep 2015;11: 1609-14.

47. Ye J, Guan Y, Zeng S, Liu D. Ampelopsin prevents apoptosis induced by H2O2 in MT-4 lymphocytes. Planta Med 2008;74:252-7.

48. Kou X, Shen K, An Y, Qi S, Dai WX, Yin Z. Ampelopsin inhibits H2O2-induced apoptosis by ERK and Akt signaling pathways and up-regulation of heme oxygenase-1. Phytother Res 2012;26:988-94.

49. Moi P, Chan K, Asunis I, Cao A, Kan YW. Isolation of NFE2-related factor 2 (Nrf2), a NF-E2-like basic leucine zipper transcriptional activator that binds to the tandem NF-E2/AP1 repeat of the beta-globin locus control region. Proc Natl Acad Sci U S A 1994:91:9926-30.

50. Nguyen T, Sherratt PJ, Nioi P, Yang CS, Pickett CB. Nrf2 controls constitutive and inducible expression of ARE-driven genes through a dynamic pathway involving nucleocytoplasmic shuttling by Keap1. J Biol Chem 2005;280:32485-92.

51. Nguyen T, Nioi P, Pickett CB. The Nrf2-antioxidant response element signaling pathway and its activation by oxidative stress. J Biol Chem 2009;284:13291-5.

52. Ma Q, Kinneer K, Bi Y, Chan JY, Kan YW. Induction of murine $\mathrm{NAD}(\mathrm{P}) \mathrm{H}$ :quinone oxidoreductase by 2,3,7,8-tetrachlorodibenzop-dioxin requires the CNC (cap ' $n$ ' collar) basic leucine zipper transcription factor Nrf2 (nuclear factor erythroid 2-related factor 2): cross-interaction between AhR (aryl hydrocarbon receptor) and Nrf2 signal transduction. Biochem J 2004:377:205-13.

53. Ikeda H, Serria MS, Kakizaki I, Hatayama I, Satoh K, Tsuchida S, et al. Activation of mouse Pi-class glutathione S-transferase gene by Nrf2(NF-E2-related factor 2) and androgen. Biochem J 2002; 364:563-70.

54. Alam J, Stewart D, Touchard C, Boinapally S, Choi AM, Cook JL. Nrf2, a Cap'n'Collar transcription factor, regulates induction of the heme oxygenase-1 gene. J Biol Chem 1999;274:26071-8.

55. He X, Lin GX, Chen MG, Zhang JX, Ma Q. Protection against chromium (VI)-induced oxidative stress and apoptosis by Nrf2. Recruiting Nrf2 into the nucleus and disrupting the nuclear Nrf2/Keap1 association. Toxicol Sci 2007:98:298-309.

56. Kim JW, Li MH, Jang JH, Na HK, Song NY, Lee C, et al. 15-Deoxy-Delta(12,14)-prostaglandin J(2) rescues PC12 cells from $\mathrm{H} 2 \mathrm{O} 2$-induced apoptosis through Nrf2-mediated upregulation of heme oxygenase-1: potential roles of Akt and ERK1/2. Biochem Pharmacol 2008; 76:1577-89.

57. Niso-Santano M, González-Polo RA, Bravo-San Pedro JM, GómezSánchez R, Lastres-Becker I, Ortiz-Ortiz MA, et al; Centro de Investigación Biomédica en Red sobre Enfermedades Neurode- generativas (CIBERNED). Activation of apoptosis signal-regulating kinase 1 is a key factor in paraquat-induced cell death: modulation by the Nrf2/Trx axis. Free Radic Biol Med 2010;48:1370-81.

58. Niture SK, Jaiswal AK. Nrf2 protein up-regulates antiapoptotic protein Bcl-2 and prevents cellular apoptosis. J Biol Chem 2012; 287:9873-86.

59. Köhler UA, Kurinna S, Schwitter D, Marti A, Schäfer M, Hellerbrand C, et al. Activated Nrf2 impairs liver regeneration in mice by activation of genes involved in cell-cycle control and apoptosis. Hepatology 2014:60:670-8.

60. Li W, Khor TO, Xu C, Shen G, Jeong WS, Yu S, et al. Activation of Nrf2-antioxidant signaling attenuates NFkappaB-inflammatory response and elicits apoptosis. Biochem Pharmacol 2008;76:1485-9.

61. Wollman EE, d'Auriol L, Rimsky L, Shaw A, Jacquot JP, Wingfield $\mathrm{P}$, et al. Cloning and expression of a cDNA for human thioredoxin. J Biol Chem 1988;263:15506-12.

62. Arnér ES, Holmgren A. Physiological functions of thioredoxin and thioredoxin reductase. Eur J Biochem 2000;267:6102-9.

63. Tanaka T, Hosoi F, Yamaguchi-Iwai Y, Nakamura H, Masutani H, Ueda S, et al. Thioredoxin-2 (TRX-2) is an essential gene regulating mitochondria-dependent apoptosis. EMBO J 2002;21:1695-703.

64. Hansen JM, Zhang H, Jones DP. Mitochondrial thioredoxin-2 has a key role in determining tumor necrosis factor-alpha-induced reactive oxygen species generation, NF-kappaB activation, and apoptosis. Toxicol Sci 2006;91:643-50.

65. Liu Y, Min W. Thioredoxin promotes ASK1 ubiquitination and degradation to inhibit ASK1-mediated apoptosis in a redox activity-independent manner. Circ Res 2002;90:1259-66.

66. Ravi D, Muniyappa H, Das KC. Endogenous thioredoxin is required for redox cycling of anthracyclines and p53-dependent apoptosis in cancer cells. J Biol Chem 2005;280:40084-96.

67. Islam KN, Kayanoki Y, Kaneto H, Suzuki K, Asahi M, Fujii J, et al. TGF-beta1 triggers oxidative modifications and enhances apoptosis in HIT cells through accumulation of reactive oxygen species by suppression of catalase and glutathione peroxidase. Free Radic Biol Med 1997:22:1007-17.

68. Lin SJ, Shyue SK, Liu PL, Chen YH, Ku HH, Chen JW, et al. Adenovirus-mediated overexpression of catalase attenuates oxLDL-induced apoptosis in human aortic endothelial cells via AP-1 and C-Jun N-terminal kinase/extracellular signal-regulated kinase mitogen-activated protein kinase pathways. J Mol Cell Cardiol 2004:36:129-39.

69. Rezvani HR, Mazurier F, Cario-André M, Pain C, Ged C, Taïeb A, et al. Protective effects of catalase overexpression on UVB-induced apoptosis in normal human keratinocytes. J Biol Chem 2006;281: 17999-8007.

70. Brown MR, Miller FJ Jr, Li WG, Ellingson AN, Mozena JD, Chatterjee $\mathrm{P}$, et al. Overexpression of human catalase inhibits proliferation and promotes apoptosis in vascular smooth muscle cells. Circ Res 1999;85:524-33.

71. Halprin KM, Ohkawara A. The measurement of glutathione in human epidermis using glutathione reductase. J Invest Dermatol 1967:48:149-52.

72. Kayanoki Y, Fujii J, Islam KN, Suzuki K, Kawata S, Matsuzawa Y, et al. The protective role of glutathione peroxidase in apoptosis induced by reactive oxygen species. J Biochem 1996;119:817-22.

73. Soares MP, Bach FH. Heme oxygenase-1: from biology to therapeutic potential. Trends Mol Med 2009;15:50-8.

74. Risom L, Møller P, Vogel U, Kristjansen PE, Loft S. X-ray-induced 
oxidative stress: DNA damage and gene expression of HO-1, ERCC1 and OGG1 in mouse lung. Free Radic Res 2003;37:957-66.

75. Garnier P, Demougeot C, Bertrand N, Prigent-Tessier A, Marie C, Beley A. Stress response to hypoxia in gerbil brain: HO- 1 and $\mathrm{Mn}$ SOD expression and glial activation. Brain Res 2001;893:301-9.

76. Wu Z, Uchi H, Morino-Koga S, Shi W, Furue M. Z-ligustilide ameliorated ultraviolet B-induced oxidative stress and inflammatory cytokine production in human keratinocytes through upregulation of $\mathrm{Nrf} 2 / \mathrm{HO}-1$ and suppression of NF-KB pathway. Exp Dermatol 2015;24:703-8.

77. Parfenova H, Basuroy S, Bhattacharya S, Tcheranova D, Qu Y, Regan RF, et al. Glutamate induces oxidative stress and apoptosis in cerebral vascular endothelial cells: contributions of HO-1 and HO-2 to cytoprotection. Am J Physiol Cell Physiol 2006;290: C1399-410.

78. Hseu YC, Chou CW, Senthil Kumar KJ, Fu KT, Wang HM, Hsu LS, et al. Ellagic acid protects human keratinocyte (HaCaT) cells against UVA-induced oxidative stress and apoptosis through the upregulation of the HO-1 and Nrf-2 antioxidant genes. Food
Chem Toxicol 2012:50:1245-55.

79. Zhang D, Shen J, Wang C, Zhang X, Chen J. GSH-dependent iNOS and HO-1 mediated apoptosis of human Jurkat cells induced by nickel(II). Environ Toxicol 2009:24:404-14.

80. Nègre-Salvayre A, Hirtz C, Carrera G, Cazenave R, Troly M, Salvayre R, et al. A role for uncoupling protein-2 as a regulator of mitochondrial hydrogen peroxide generation. FASEB J 1997;11: 809-15.

81. Cao T, Dong Y, Tang R, Chen J, Zhang CY, Zen K. Mitochondrial uncoupling protein 2 protects splenocytes from oxidative stressinduced apoptosis during pathogen activation. Cell Immunol 2013:286:39-44

82. Lee KU, Lee IK, Han J, Song DK, Kim YM, Song HS, et al. Effects of recombinant adenovirus-mediated uncoupling protein 2 overexpression on endothelial function and apoptosis. Circ Res 2005; 96:1200-7.

83. Chen XL, Tang WX, Tang XH, Qin W, Gong M. Downregulation of uncoupling protein-2 by genipin exacerbates diabetes-induced kidney proximal tubular cells apoptosis. Ren Fail 2014;36:1298-303. 